\title{
Investigations on breeding plans for organic dairy cattle
}

\begin{abstract}
Based on an inquiry of ecological organisations, animal breeding organisations, and processing- and marketing facilities in Germany, different alternative breeding plans for organic cattle breeding were developed using the computer program ZPLAN. First the impact of the population size on the parameters of success was analysed. A conventional cattle breeding program was compared with an organic breeding program. The results indicate that the selection response increased with increasing population size due to improved selection of bull sires. The EU Regulations on organic farming say that the proportion of artificial insemination has to be reduced as much as possible. According to this, the influence of different proportions of artificial insemination on the monetary genetic gain was investigated. The reduction of artificial insemination below $50 \%$ led to high losses in the discounted profit. The influence of higher economic weights for functional traits on the natural selection response was investigated. An increase of the economic weights by $50 \%$ led to tolerable decreases in the natural selection response of production traits with regard to a more ecological orientated breeding goal. The effect of the variation of the test capacity and the number of test bulls on the monetary genetic gain was analysed. The optimum for the monetary genetic gain was located at a test capacity of 50\%, 30 test bulls and 99 daughters per test bull.
\end{abstract}

Key Words: ecological breeding program, functional traits, artificial insemination, progeny testing scheme, population size

\section{Zusammenfassung}

Titel der Arbeit: Zuchtplanung für die Rinderzucht im ökologischen Landbau

Auf Basis einer Befragung von ökologischen Verbänden, Rinderzuchtorganisationen sowie Vermarktungs- und Verarbeitungsbetrieben wurden verschiedene Zuchtprogrammvarianten für die Rinderzucht im ökologischen Landbau untersucht. Zunächst wurde anhand eines Vergleiches zwischen einem konventionellen und einem ökologischen Zuchtprogramm der Einfluss der Populationsgröße auf die Erfolgsparameter analysiert. Die Ergebnisse zeigen, dass mit zunehmender Populationsgröße auch der Züchtungserfolg zunimmt. Dies ist auf die verbesserte Selektion im Bullenväterpfad zurückzuführen. Aufbauend auf der EU-Verordnung zum ökologischen Landbau wurde im Anschluss der Einfluss unterschiedlicher Anteile künstlicher Besamung evaluiert. Die Untersuchung zeigt, dass der Anteil künstlicher Besamung nicht unter 50 \% fallen sollte, da eine weitere Senkung desselben zu einer erheblichen Reduzierung des Gewinns führt. Darüber hinaus wurde der Einfluss einer Erhöhung der wirtschaftlichen Gewichte für die funktionalen Merkmale untersucht. Aus den Ergebnissen wird deutlich, dass eine Erhöhung der wirtschaftlichen Gewichte um 50 \% zu tolerierbaren Einbußen in den naturalen Zuchtfortschritten der Produktionsmerkmale führt, wenn das Zuchtziel vor allem die Verbesserung der funktionalen Merkmale beinhaltet. Abschließend wurde der Einfluss der Variation der Testkapazität und der Anzahl Testbullen auf den monetären Zuchtfortschritt ermittelt. Das Optimum für den monetären Zuchtfortschritt lag bei einer Testkapazität von 50 \%, 30 Testbullen und 99 Töchtern pro Testbulle.

Schlüsselwörter: Ökologisches Zuchtprogramm, funktionale Merkmale, künstliche Besamung, Nachkommenprüfung, Populationsgröße

1.

Introduction

In Germany the proportion of ecological managed milk-farms is about 2,5\% (STATISTISCHES BUNDESAMT, 2002) of all milk-farms. This corresponds to a number of about 102,000 cows distributed over 3300 herds. General conditions for 
animal breeding in organic farming are defined by the EU Regulations on organic farming (REGULATION No. 1804, 1999). According to these regulations a decrease of the proportion of artificial insemination is desired. In order to get more information about special breeding strategies in organic farming we carried out a status quo analysis (HARDER et al. 2003, unpublished). An inquiry of the ecological organisations, the animal breeding organisations, and the processing- and marketing facilities was included in the analysis. The ecological organisations emphasised the importance of functional traits and in particular functional longevity in the total merit index. Functional traits are defined as those characteristics of an animal, which increase the efficiency by reducing costs. They include the trait complexes health, fertility, calving ease, efficiency of feed utilisation and milkability (GROEN et al., 1997). Additionally, the trait persistency is important in organic dairy breeding, because by improving persistency the concentrate intake can be reduced. According to the inquiry, the breeding goal in organic cattle breeding should put more weight on the functional traits and by doing this accepts a lower genetic gain for the production traits. This is due to ethical aspects with regard to animal welfare, that should be taken into account in organic animal breeding. Furthermore, DISTL (1995) claimed that a higher emphasis on animal welfare leads to a higher consumer acceptance.

The ecological total merit index for Simmental, Brown Swiss and Yellow Cattle developed by a working group in Bavaria, was a first approach for building up an own breeding structure for organic dairy cattle breeding. Further information concerning the contribution of the total merit index are described in KROGMEIER (2003).

The aim of this study was to evaluate several breeding plans for organic cattle breeding with the computer program ZPLAN (NITTER et al., 1999). The impact of different proportions of artificial insemination, different economic weights for the functional traits, and different test capacities on the criteria monetary genetic gain, natural selection response, and discounted profit was investigated.

\section{2.} Material and Methods

The computer program ZPLAN, described by NITTER et al. (1999), was used to model a breeding program for organic cattle breeding in Germany. ZPLAN enables to evaluate different breeding plans in any livestock species and optimise them according to several criteria, such as the genetic gain for the breeding objective, natural selection response for single traits, and return on investment adjusted for costs. The annual monetary genetic gain is defined as the monetary superiority per year of the progeny of the selected animals of one round of selection in the breeding unit. The natural selection response is defined as the natural superiority per year of the progeny of the selected animals in a single trait. The discounted profit is defined as discounted return minus discounted breeding costs per cow; discounted return is the monetary value of the genetic superiority of the selected animals in the whole population, i.e. breeding and production unit, over the time of investment.

The ZPLAN program is based on the gene-flow method described by MC CLINTOCK and CUNNINGHAM (1974), HILL (1974), ELSEN and MOCQUOT (1974), and BRASCAMP (1978). By the use of the gene-flow method the economic values for each trait in each selection group are weighted by the number of standardised discounted expressions. The selection groups are specific for their information sources and selection intensities. The division of the whole population into different selection 
groups is the basis for building up the transmission matrix, consisting of reproduction and ageing groups. The transmission matrix with 15 selection groups is shown in Table 1.

Table 1

Transmission matrix of the breeding plan with 15 selection groups (Übertragungsmatrix für den Ausgangszuchtplan mit 15 Selektionsgruppen)

\begin{tabular}{|c|c|c|c|c|c|}
\hline & $\mathrm{OB}^{*}$ & NSB* & FOB* & CBU* & CPU* \\
\hline OB & 1. $\mathrm{OB}>\mathrm{OB}$ & -- & 2. $\mathrm{FOB}>\mathrm{OB}$ & 3. $\mathrm{CBU}>\mathrm{OB}$ & -- \\
\hline NSB & $\begin{array}{l}\text { 4. } \mathrm{TB}^{*}>\mathrm{NSB} \\
\text { 5. } \mathrm{OB}>\mathrm{NSB}\end{array}$ & -- & -- & 6. $\mathrm{CBU}>\mathrm{NSB}$ & -- \\
\hline $\mathrm{CBU}$ & $\begin{array}{l}\text { 7. } \mathrm{TB}>\mathrm{CBU} \\
\text { 8. } \mathrm{OB}>\mathrm{CBU}\end{array}$ & 9. $\mathrm{NSB}>\mathrm{CBU}$ & 10. $\mathrm{FOB}>\mathrm{CBU}$ & 11. $\mathrm{CBU}>\mathrm{CBU}$ & -- \\
\hline CPU & $\begin{array}{l}\text { 12. } \mathrm{TB}>\mathrm{CPU} \\
\text { 13. } \mathrm{OB}>\mathrm{CPU}\end{array}$ & 14. NSB $>C P U$ & -- & -- & 15. $\mathrm{CPU}>\mathrm{CPU}$ \\
\hline
\end{tabular}
bulls

Selection groups one to eleven describe the breeding unit, whereas selection groups twelve to fifteen model the production level. Groups two and ten show the impact of bulls from other populations in the breeding unit. The use of bulls for natural service is modelled by selection groups four, five, nine and fourteen. Groups eleven and fifteen represent cows to breed cows in the breeding unit (CBU to breed $\mathrm{CBU}$ ) and in the production unit (CPU to breed CPU), respectively. The transfer of genetic gain from the breeding to the production unit is described by selection groups twelve, thirteen and fourteen. In the organic breeding program a population size of 50,000 cows was assumed. According to the inquiry $80 \%$ of the cows were under milk recording and $80 \%$ artificial insemination was presumed. This results in an active population size of 32,000 cows. A waiting bull system with planned mating and two-step selection and without embryo transfer is assumed. The main input parameters are given in Table 2.

Table 2

Biological coefficients of the initial breeding plan (Biologisch-technische Koeffizienten des Ausgangszuchtplanes)

\begin{tabular}{lrr}
\hline Input parameters & Unit & Value \\
\hline Total population size & number & 50,000 \\
Proportion of recorded cows & $\%$ & 80 \\
Proportion of artificial insemination & $\%$ & 80 \\
Proportion of test bulls & $\%$ & 20 \\
Test bulls/year & number & 12 \\
Bull dams/year & number & 58 \\
Old bulls/year & number & 7 \\
Bull sires/year & number & 2 \\
Calving interval & year & 1.09 \\
Insemination index & number & 2 \\
Raising losses (female) & $\%$ & 5.1 \\
Raising losses (male) & $\%$ & 5.1 \\
Stillbirth rate & $\%$ & 10 \\
Productive life test bulls & year & 0.25 \\
Productive life old bulls & year & 2.2 \\
Productive life bull dams & year & 2.0 \\
\hline
\end{tabular}


Table 3

Phenotypic correlations (upper triangle), genetic correlations (lower triangle) and heritabilities (diagonal elements) of the traits included in the breeding goal (Phänotypische Korrelationen oberhalb der Diagonale, genetische Korrelationen unterhalb der Diagonale und Heritabilitäten der Merkmale im Gesamtzuchtwert auf der Diagonale)

\begin{tabular}{|c|c|c|c|c|c|c|c|c|c|c|c|c|c|}
\hline & Trait & 1 & 2 & 3 & 4 & 5 & 6 & 7 & 8 & 9 & 10 & 11 & 12 \\
\hline 1 & Milk yield & 0.25 & 0.86 & 0.90 & 0.15 & -0.06 & -0.06 & 0.00 & 0.00 & 0.00 & 0.00 & 0.02 & 0.10 \\
\hline 2 & Fat yield & 0.65 & 0.21 & 0.77 & 0.11 & -0.05 & -0.05 & 0.00 & 0.00 & 0.00 & 0.00 & 0.04 & 0.00 \\
\hline 3 & Protein yield & 0.82 & 0.64 & 0.23 & 0.17 & -0.07 & -0.07 & 0.00 & 0.00 & 0.00 & 0.00 & 0.04 & 0.00 \\
\hline 4 & SCS & 0.15 & 0.11 & 0.27 & 0.12 & 0.00 & 0.00 & 0.00 & 0.00 & 0.00 & 0.00 & 0.44 & 0.00 \\
\hline 5 & Fertility maternal & -0.37 & -0.20 & -0.20 & 0.10 & 0.02 & 0.00 & 0.00 & 0.00 & 0.00 & 0.00 & 0.00 & 0.00 \\
\hline 6 & Fertility paternal & -0.50 & -0.10 & -0.10 & 0.10 & -0.20 & 0.02 & 0.00 & 0.00 & 0.00 & 0.00 & 0.00 & 0.00 \\
\hline 7 & Calving ease pat. & -0.10 & -0.10 & -0.10 & 0.00 & 0.00 & 0.00 & 0.05 & 0.00 & 0.15 & 0.00 & 0.00 & 0.00 \\
\hline 8 & Calving ease mat. & 0.10 & 0.10 & 0.10 & 0.00 & 0.00 & 0.00 & -0.09 & 0.05 & 0.00 & 0.15 & 0.00 & 0.00 \\
\hline 9 & Stillbirth paternal & 0.00 & 0.00 & 0.00 & 0.00 & 0.00 & 0.00 & 0.60 & 0.00 & 0.05 & 0.00 & 0.00 & 0.00 \\
\hline 10 & Stillbirth maternal & 0.00 & 0.00 & 0.00 & 0.00 & 0.00 & 0.00 & 0.00 & 0.60 & -0.12 & 0.05 & 0.00 & 0.00 \\
\hline 11 & Functional longevity & -0.10 & -0.10 & -0.10 & 0.23 & 0.10 & 0.10 & 0.00 & 0.16 & 0.00 & 0.15 & 0.10 & 0.00 \\
\hline 12 & Persistency & 0.20 & 0.00 & 0.00 & 0.00 & 0.00 & 0.00 & 0.00 & 0.00 & 0.00 & 0.00 & 0.00 & 0.14 \\
\hline
\end{tabular}

ZPLAN needs a matrix with genetic correlations, heritabilities, phenotypic standard deviations and phenotypic correlations. Table 3 shows the traits included with the assumed genetic parameters derived from literature (GENGLER, 1996; HINRICHS, 2003; JAKOBSEN et al., 2001; KATHENBRINK and SWALVE, 1993; LINDHÉ and PHILIPSSON, 1995; MEIJERING, 1984; MIESENBERGER, 1997; PETERSEN, 2002; RUPP and BOICHARD, 1999; SCHOMAKER, 2001; SÖLKNER et al., 2000; THALLER and AUMANN, 1996; VAN DORP et al., 1998; VIT, 2002; VOLLEMA et al., 2000) The functional traits considered were paternal and maternal stillbirth and calving ease, i.e. the effect of calf and the effect of mother of calf, respectively. Fertility was defined as nonreturn rate $90 \mathrm{~d}$, considering the maternal effect, i.e. the effect of the cow and the paternal effect, i.e. the effect of sire. The other functional traits considered were longevity adjusted for relative milk yield, somatic cell score and persistency.

The economic weights for the traits were mainly taken from MACK (1996) and MIESENBERGER et al. (1998) and are shown in Table 4.

Table 4

Genetic standard deviations $\left(\mathrm{s}_{\mathrm{A}}\right)$ and economic weights $(€)$ per genetic standard deviation included in the breeding goal (Genetische Standardweichungen und ökonomische Gewichte pro genetischer Standardabweichung im Gesamtzuchtwert)

\begin{tabular}{lccr}
\hline Trait & unit & $\mathrm{s}_{\mathrm{A}}$ & Economic weight $/ \mathrm{s}_{\mathrm{A}}$ \\
\hline Milk & $\mathrm{kg}$ & 450 & 34.51 \\
Fat & $\mathrm{kg}$ & 19.7 & 13.80 \\
Protein & $\mathrm{kg}$ & 13.4 & 37.28 \\
Persistency & $\mathrm{s}_{\mathrm{A}}$ & 1 & 2.91 \\
Somatic cell count & $\mathrm{s}_{\mathrm{A}}$ & 1 & 14.53 \\
Fertility maternal & $\%$ & 5 & 7.25 \\
Fertility paternal & $\%$ & 5 & 7.25 \\
Calving ease paternal & class & 0.25 & 0.71 \\
Calving ease maternal & class & 0.25 & 0.71 \\
Stillbirth paternal & $\%$ & 2.5 & 1.10 \\
Stillbirth maternal & $\%$ & 2.5 & 1.10 \\
Productive life & day & 180 & 22.00 \\
\hline
\end{tabular}




\section{Organic versus conventional breeding program}

At first a comparison of the organic breeding program (Table 2) with a conventional breeding program was carried out. The organic breeding program was assumed to have $10 \%$ of the breeding population of the conventional breeding program. Therefore, the active population size in the conventional breeding program was 320,000 cows. In the conventional breeding program we assumed the same proportions of recorded cows, of artificial insemination and of test bulls as in the organic breeding program. Due to this, higher numbers of animals in the different paths of selection were calculated. Contrary to the organic breeding program, embryo transfer for $30 \%$ of the bull dams was assumed. In the program this was accounted by increasing the probability of getting a bull calf, and by increasing the number of full-sib information. The use of embryo transfer led to higher variable costs in the conventional breeding program. The effects of different population sizes and the impact of embryo transfer on return, costs, and profit was investigated.

\section{Natural service}

The influence of different proportions of artificial insemination on monetary genetic gain, natural selection response, and discounted profit was investigated. Starting from $80 \%$ artificial insemination in the breeding unit and $70 \%$ artificial insemination on the production level the proportion of artificial insemination was continuously reduced. Analyses were carried out for 80, 60, 40 and 20\% artificial insemination in the breeding unit and 70, 50, 30 and 10\% artificial insemination in the production unit, respectively.

\section{Economic weights of functional traits}

The influence of different economic weights for the functional traits was investigated. Milk, fat and protein yield are combined in the subindex "Production", whereas all other traits, i.e. the functional traits, are assigned to the subindex "Fitness". Following BAUMUNG et al. (2001) the weights of the traits, constituting the subindex "Fitness" in the total merit index were increased arbitrarily by $50 \%$ and by $100 \%$. This implicates that the change of the economic weights was not economically founded.

\section{Variation of test capacity}

The accuracy of the estimated breeding values is a function of the heritability and the number of daughters per test bull. Because the heritabilities of the functional traits are low, the number of daughters should be higher to achieve a high accuracy. Therefore, the impact of variation of test capacity and number of test bulls on the monetary selection response was investigated. In the basic situation $20 \%$ test capacity and 12 young bulls tested per year were assumed. The test capacity was varied between 10 , $20,30,40,50,60$, and $70 \%$, and the number of young bulls was varied between 12 , 18,24 , and 30 , respectively.

\section{Results and discussion}

3.1 Organic versus conventional breeding program

The parameters of success of the two breeding programs are given in Table 5 . The results show clearly that the conventional breeding program was superior to the organic in all parameters. First of all the superiority of the conventional breeding program was due to the population size. This was mainly caused by the improved 
selection of bull sires. More test bulls were needed, and therefore more young bulls with an adequate number of daughters were tested. Similar results were shown by NIEBEL and FEWSON (1978). In the conventional breeding program embryo transfer for bull dams was used. Due to the embryo transfer an increased selection intensity for bull dams and a higher accuracy for the breeding value estimation was achieved.

Table 5

Monetary genetic gain $(€)$, return $(€)$, costs $(€)$, and profits $(€)$ for the organic and the conventional breeding program, respectively (Monetärer Zuchtfortschritt, Züchtungsertrag, Züchtungskosten und Züchtungsgewinn für das konventionelle und das ökologische Zuchtprogramm)

\begin{tabular}{lcc}
\hline Parameters of success & $\begin{array}{c}\text { Organic breeding } \\
\text { program }\end{array}$ & $\begin{array}{c}\text { Conventional breeding } \\
\text { program }\end{array}$ \\
\hline Monetary genetic gain & 9.36 & 11.70 \\
Return & 56.30 & 71.48 \\
Costs & 31.34 & 31.08 \\
Profit & 24.96 & 40.40 \\
\hline
\end{tabular}

\subsection{Natural service}

The decrease of the proportion of artificial insemination caused a deterioration of all parameters (Table 6). This is most obvious regarding the profit. Compared with the initial situation the profit in alternative 1 decreased by $15 \%$. The decrease in the other two alternatives is even stronger. The profit in alternative three was about $8 €$. This was about $70 \%$ lower than in the basic situation. This was due to the decrease of the selection intensity for the natural service bulls. Furthermore, natural service bulls had only a few daughters. Therefore, the accuracy of the estimated breeding value deteriorated when reducing the proportion of artificial insemination in the population. When the proportion of artificial insemination decreased the active population size decreased as well by definition. This led to a decline of the selection intensity for bull dams and furthermore to a decreased number of test bulls in the population. In contrast to these results GESER (1992) pointed out that the increase of the proportion of artificial insemination had only little influence on the profit of the breeding plan, but it has to be considered that the author only varied the proportion of artificial insemination between 40 and $80 \%$.

Table 6

Absolute values and relative differences (\%) of monetary genetic gain $(€)$, return $(€)$, and profit (€), as a function of artificial insemination (Absolutwerte und relative Unterschiede in Prozent von monetärem Zuchtfortschritt (€), Züchtungsertrag (€) und Züchtungsgewinn (€) bei Variation des Anteils künstlicher Besamung)

\begin{tabular}{lcccr} 
Parameters of success & $\begin{array}{c}\text { Initial situation } \\
\text { CBU 80 }\end{array}$ & $\begin{array}{c}\text { Alternative 1 } \\
\text { CBU = 60 }\end{array}$ & $\begin{array}{c}\text { Alternative 2 } \\
\text { CBU = 40 }\end{array}$ & $\begin{array}{c}\text { Alternative 3 } \\
\text { CBU = 20 }\end{array}$ \\
\hline Monetary genetic gain/year & 9.61 & 8.84 & 7.85 & 6.24 \\
Variation (\%) & 0 & -8.01 & -18.32 & -35.07 \\
Return & 58.54 & 52.85 & 45.41 & 34.30 \\
Variation (\%) & 0 & -9.72 & -22.43 & -41.41 \\
Profit & 26.50 & 22.65 & 16.95 & 7.68 \\
Variation (\%) & 0 & -14.53 & -36.04 & -71.02 \\
\hline
\end{tabular}

1) $\mathrm{CBU}=$ Cows breeding unit; $80 \%$ artificial insemination

2) $\mathrm{CPU}=$ Cows production unit; $70 \%$ artificial insemination

\subsection{Economic weights for the functional traits}

Table 7 shows that the increase of the economic weights of the functional traits led to an adjustment of the subindices "Production" and "Fitness" favouring the "Fitness value". 
Table 7

Relative economic importance of the subindices "Production " and "Fitness" as a function of the economic weights for the functional traits (Relative Bedeutung der Subindices "Produktion” und "Fitness” bei Erhöhung der wirtschaftlichen Gewichte)

\begin{tabular}{lcc}
\hline Scenario & Production & Fitness \\
\hline Basic situation & $59 \%$ & $41 \%$ \\
$+50 \%$ & $49 \%$ & $51 \%$ \\
$+100 \%$ & $41 \%$ & $59 \%$ \\
\hline
\end{tabular}

The influence of higher economic weights for the functional traits on the natural selection response of the traits is shown in Table 8. In the initial situation selection led to an improvement in all traits except for the paternal calving ease. With increase of the economic weights of the functional traits the selection response of the production traits deteriorated. Table 8 illustrates that with higher economic weights for the functional traits the selection response for milk yield decreased by 28 and 52\%, respectively. Similar results were presented by BAUMUNG et al. (2001). In contrast to the production traits the higher weights for the functional traits led to an improvement of all traits combined in the "Fitness value". In both alternatives an increase of the selection response of the functional traits could be observed. This trend is most obvious regarding functional longevity. The increase of the economic weights by $100 \%$ elongated functional longevity by about 6 days. Admittedly, despite the higher weights for the functional traits a small negative response of paternal calving ease was observed. BAUMUNG et al. (2001) also showed a negative response for paternal calving ease and additionally for paternal stillbirth.

Table 8

Natural selection response of the traits included in the breeding goal as a function of the economic weights of the functional traits (Naturale Zuchtfortschritte der Merkmale im Gesamtzuchtwert bei Erhöhung der wirtschaftlichen Gewichte der funktionalen Merkmale um 50 \% und um $100 \%$ )

\begin{tabular}{lccrr}
\hline Traits & unit & Basic situation & $+50 \%$ & $+100 \%$ \\
\hline Milk yield & $\mathrm{kg}$ & 41.040 & 29.370 & 19.610 \\
Fat yield & $\mathrm{kg}$ & 2.105 & 1.733 & 1.410 \\
Protein yield & $\mathrm{kg}$ & 1.866 & 1.553 & 1.269 \\
\hline Persistency & $\mathrm{s}_{\mathrm{A}}$ & 0.004 & 0.005 & 0.006 \\
Somatic cell score & points & 0.096 & 0.111 & 0.119 \\
Fertility maternal & $\%$ & 0.002 & 0.062 & 0.107 \\
Fertility paternal & $\%$ & 0.162 & 0.231 & 0.277 \\
Calving ease paternal & class & -0.004 & -0.003 & -0.002 \\
Calving ease maternal & class & 0.007 & 0.008 & 0.008 \\
Stillbirth paternal & $\%$ & 0.000 & 0.0001 & 0.0002 \\
Stillbirth maternal & $\%$ & 0.036 & 0.045 & 0.050 \\
Functional longevity & day & 9.685 & 13.510 & 16.060 \\
\hline
\end{tabular}

\subsection{Variation of test capacity}

The annual monetary genetic gain changed with variation of test capacity and number of test bulls. According to Table 9 highest values for the monetary genetic gain were reached at a test capacity of 50\%, 30 test bulls, and 99 daughters per test bull, although there was no pronounced optimum in the investigations.

Increasing the test capacity led to a higher demand for test bulls and therefore the selection intensity for bull sires and cow sires increased. The higher proportion of young bulls led to a shorter generation interval. In this investigation the generation interval was reduced by about half a year from a test capacity of $10 \%$ to a test capacity of $70 \%$ (not shown). Besides these positive effects on the annual monetary genetic 
gain the increasing test capacity needed more test bulls and therefore the selection intensity for the test bulls declined. The higher number of test bulls required more bull dams, which decreased their selection intensity as well. According to WILLAM et al. (2002) the optimum for the Austrian Brown Swiss cattle was estimated at a test capacity of 30\% and 45 test bulls. Similar results were shown by RIEDL (1996) and HECKENBERGER (1991). Similar to this investigation WILLAM et al. (2002) pointed out that the differences between the alternatives were very small. The optimum number of daughters per test bull was around 100 (Table 9). A further increase of the number of daughters per test bull had only little impact on the annual monetary genetic gain (Table 9). However, the increase of the number of daughters per test bull changed the composition of the monetary genetic gain favouring the functional traits (Table 10). Similar results were shown by SØRENSEN et al. (1999). They reasoned that an increased size of daughter group caused lower genetic gain for milk production and a higher one for cost reducing traits with low heritabilities, but on average their was no effect on total genetic gain. The authors recommended a number of 160 test bull daughters.

Table 9

Effect of test capacity and number of test bulls on the annual monetary genetic gain (€); (in brackets the number of daughters) (Einfluss der Testkapazität auf den monetären Zuchtfortschritt (€); (Anzahl Töchter in Klammern))

Number of test bulls

$\begin{array}{lllll}\text { test capacity } & 12 & 18 & 24 & 30\end{array}$

\begin{tabular}{rlllr}
\hline $10 \%$ & $8.95(49)$ & $9.10(33)$ & $9.04(24)$ & $8.93(19)$ \\
$20 \%$ & $9.37(99)$ & $9.65(66)$ & $9.69(49)$ & $9.66(39)$ \\
$30 \%$ & $9.53(148)$ & $9.82(99)$ & $9.92(74)$ & $9.92(59)$ \\
$40 \%$ & $9.60(198)$ & $9.89(131)$ & $9.99(99)$ & $10.01(79)$ \\
$50 \%$ & $9.62(247)$ & $9.89(164)$ & $9.99(123)$ & $10.02(99)$ \\
$60 \%$ & $9.62(297)$ & $9.86(198)$ & $9.94(148)$ & $9.95(118)$ \\
$70 \%$ & $9.61(346)$ & $9.80(230)$ & $9.86(173)$ & $9.86(138)$ \\
\hline
\end{tabular}

Table 10

Change of the composition of the annual monetary genetic gain when increasing the number of daughters/test bull (number of daughters/TB in brackets); the number of test bulls is fixed (18) (Veränderung der Zusammensetzung des monetären Zuchtfortschrittes bei Erhöhung der Anzahl Töchter/Testbulle; konstante Anzahl Testbullen(18))

\begin{tabular}{lccccccc}
\hline $\begin{array}{l}\text { Test capacity } \\
(\%)\end{array}$ & $\begin{array}{c}\text { Production } \\
\text { traits } \\
(\%)\end{array}$ & $\begin{array}{c}\text { SCS } \\
(\%)\end{array}$ & $\begin{array}{c}\text { Fertility } \\
(\%)\end{array}$ & $\begin{array}{c}\text { Calving } \\
\text { ease } \\
(\%)\end{array}$ & $\begin{array}{c}\text { Stillbirth } \\
(\%)\end{array}$ & $\begin{array}{c}\text { Longevity } \\
(\%)\end{array}$ & $\begin{array}{l}\text { Persistency } \\
(\%)\end{array}$ \\
\hline $10 \%(33)$ & 71.90 & 14.38 & 2.39 & 0.115 & 0.398 & 10.71 & 0.105 \\
$20 \%(66)$ & 70.23 & 14.75 & 2.39 & 0.118 & 0.413 & 11.97 & 0.124 \\
$30 \%(99)$ & 69.48 & 14.91 & 2.41 & 0.118 & 0.417 & 12.54 & 0.129 \\
$40 \%(131)$ & 69.09 & 15.00 & 2.41 & 0.118 & 0.417 & 12.83 & 0.130 \\
$50 \%(164)$ & 68.84 & 15.05 & 2.46 & 0.118 & 0.417 & 12.99 & 0.128 \\
$60 \%(198)$ & 68.62 & 15.09 & 2.56 & 0.116 & 0.415 & 13.07 & 0.125 \\
$70 \%(230)$ & 68.29 & 15.11 & 2.86 & 0.115 & 0.412 & 13.09 & 0.122 \\
\hline
\end{tabular}

The contribution of the traits included in the breeding goal to the annual monetary genetic gain is shown in Table 10. A situation with 18 test bulls and an increasing test capacity and therefore an increasing number of test bull daughters was assumed. According to Table 10 the two most important functional traits were functional longevity and somatic cell score. At a test capacity of $20 \%$ both traits together contribute about $26 \%$ to the annual monetary genetic gain. Comparing a test capacity 
of $10 \%$ with a test capacity of $70 \%$ the contribution of functional longevity to the annual monetary genetic gain increased by about $20 \%$.

\section{Conclusions}

Interpreting the results of the breeding alternatives one should be aware of the fact, that the assumed parameters play a considerable role. Under the assumed parameters the development of a breeding program for organic cattle breeding should consider the following. According to the comparison of the conventional with the organic breeding program an adequate population size for the organic breeding program has to be achieved. The breeding program should be developed throughout Germany to get an adequate population size of at least 50,000 cows. Besides that, the EU Regulations on organic farming stipulate a higher proportion of natural service bulls. However, the proportion of artificial insemination should not be less than 50\%. Otherwise the profit decreases drastically.

The increase of the economic weights of the functional traits by 50 and by $100 \%$ results in an improvement of the natural selection responses of the functional traits. However, the natural selection response of the production traits decreases. The breeding goal in organic breeding aims more at a high lifetime performance, because lactations of for example $10,000 \mathrm{~kg}$ milk are only possible through the use of high levels of concentrate feeds. According to this, a breeding goal putting more emphasis on the functional traits is a good alternative. Therefore, an increase of the economic weights of the cost reducing functional traits can be a reasonable possibility.

Another opportunity to improve the selection response of functional traits is a higher number of daughters per test bull. An increased number of daughter records has a positive effect on the monetary genetic gain of the functional traits. The optimum number of daughter records per test bull depends on the objective to be optimised. From an economic point of view an increase of the number of daughters records up to 100 or more has only little influence on the monetary genetic gain of all traits, but the composition of the monetary genetic gain is changed favouring the functional traits. According to this, the number of daughters per test bull for an organic breeding program should be around 100 or even above.

\section{Acknowledgements}

Financial support from the German Ministry of Consumer Protection, Food and Agriculture is gratefully acknowledged.

\section{References}

BAUMUNG, R.; SÖLKNER, J.; GIERZINGER, E.; WILLAM, A.:

Ecological total merit index for an Austrian dual purpose cattle breed. Arch. Tierz., Dummerstorf 44 (2001) 1, 5-13

BRASCAMP, E.W.:

Deterministic model and monte carlo method. In: Methods on economic optimisation of animal breeding plans. University of Wageningen Rapport B-134 (1978), 11-15

DISTL, O.:

Ansätze zur Entwicklung einer Leistungsprüfung für Gesundheit. In: Rinder-Workshop Uelzen 1995, 91-110

ELSEN, J.M.; MOCQUOT, J.C.:

Méthode de prévision de l'évolution du niveau génétique d’une population soumise à une opération de sélection et dont les générations se chevauchent. INRA Bull. tech. Dépt. Génét. Anim. 17 (1974), 30-54 
GENGLER, N.:

Persistency of lactation yields: a review. Workshop on genetic improvement of functional traits in cattle. Interbull Bull. 12 (1996), 87-95

GESER, M.:

Theoretische Grundlagen und organisatorische Rahmenbedingungen für die Durchführung eines MOET-Zuchtprogrammes bei der Pinzgauerrasse. University of Agricultural Sciences, Vienna, Diss. (1992)

GROEN, A.F.; STEINE, T.; COLLEAU, J.-J.; PEDERSEN, J.; PRIBYL, J.; REINSCH, N.:

Economic values in dairy cattle breeding, with special reference to functional traits. Report of an EAAP-working group. Livest. Prod. Sci. 49 (1997), 1-21

HARDER, B.; JUNGE, W.; BENNEWITZ, J.; KALM, E.:

Status Quo Analyse über die Möglichkeiten und Erfordernisse in der ökologischen Rinder- und Schweinezucht, (2003), not published

HECKENBERGER, G.J.:

Planungsrechnungen über den Einfluß von Grenznutzenwerten der Leistungsmerkmale, Parameter der Populationsstruktur und von Züchtungssystemen auf den Züchtungserfolg beim Zweinutzungsrind. University Stuttgart-Hohenheim, Diss. (1991)

HILL, W.G.:

Prediction and evaluation of response to selection with overlapping generations. Animal Production 18

HINRICHS, D.: (1974), 117-139

Untersuchungen zur gelenkten Feldprüfung. University of Kiel, Diss. in preparation

JAKOBSEN, J.H.; MADSEN, P.; JENSEN, J.; PEDERSEN, J.; CHRISTENSEN, L.G.; SØRENSEN, D.A.:

Genetic parameters for milk production and persistency for Danish Holsteins estimated in Random Regression Models using REML. J. Dairy Sci. 85 (2001), 1607-1616

KATHENBRINK, S.; SWALVE, H.:

Untersuchungen zur Erblichkeit von Leistungsvariablen der ersten Laktation von Milchkühen. Züchtungskunde 65 (1993), 254-266

KROGMEIER, D.:

Der Ökologische Gesamtzuchtwert für Fleckvieh, Braunvieh und Gelbvieh. Beitrag zur Konferenz: Forschung für den ökologischen Landbau in Bayern. Schriftenreihe der Bayerischen Landesanstalt für Landwirtschaft (3/2003), 77-86

LINDHE, B. ; PHILIPSSON, J.:

Effect of unknown vs. known genetic relationships between economically important traits in total merit

MACK, G.: indexes for dairy cattle. 46. Annual Meeting of the EVT Prague (1995), G.3.7

Wirtschaftlichkeit des züchterischen Fortschritts in Milchviehherden; Gesamtbetriebliche Analyse mit Hilfe eines simultan-dynamischen Linearen Planungsansatzes. University of Stuttgart-Hohenheim, Diss. (1996)

MC CLINTOCK, A.E.; CUNNINGHAM, E.P.:

Selection in dual purpose cattle populations: Defining the breeding objective. Animal Production 18 (1974), 237-247

MEIJERING, A.:

Dystocia and stillbirth in cattle - A review of causes, relations and implications. Livest. Prod. Sci. 11 (1984), 143-177

MIESENBERGER, J.:

Zuchtzieldefinition und Indexselektion für die österreichische Rinderzucht. University of Agricultural Sciences, Vienna, Diss. (1997)

MIESENBERGER, J.; SÖLKNER, J.; ESSL, A.:

Economic weights for fertility and reproduction traits relative to other traits and effects of including functional traits into a total merit index. Proc. Internat. Workshop on Genetic Improvement of Functional Traits in Cattle, Grub, Germany, Nov. 1997; Interbull Bull. 18 (1998), $78-84$

NIEBEL, E.; FEWSON, D.:

Untersuchungen zur Zuchtplanung für die Reinzucht beim Zweinutzungsrind. 5. Effektivität verschiedener Züchtungssysteme bei unbegrenzt verfügbaren Investitionsmitteln. Züchtungskunde 50 (1978), 333-345

NITTER, G.; BARTENSCHLAGER, H.; KARRAS, K.; NIEBEL, E.; GRASER, H.-U.:

ZPLAN: a PC computer program to optimize livestock selection schemes. User's Guide for ZPLAN, Version 1999, University Hohenheim 


\section{PETERSEN, T::}

Genetische Analysen von Fruchtbarkeitsdaten aus Herdenmanagementprogrammen beim Milchrind. Schriftenreihe des Instituts für Tierzucht und Tierhaltung der Christian-Albrechts-Universität zu Kiel, Heft 134 (2002)

REGULATION EC No. 1804:

Council Regulation (EC) No. 1804 supplementing Regulation (EEC) No 2092/1991 on organic production of agricultural products and indications referring thereto on agricultural products and RIEDL, M.: foodstuffs to include livestock production (1999), L. 222, 1ff.

Untersuchungen zur Optimierung des Züchtungserfolges eines konventionellen Besamungszuchtprogrammes für Milchrinder am Beispiel der sächsischen Schwarzbuntpopulation. University of Leipzig, Diss. (1996)

RUPP, R.; BOICHARD, J.:

Genetic parameters for clinical mastitis, somatic cell score, production, udder type traits and milking ease in first lactating Holsteins. J. Dairy Sci. 82 (1999), 2198-2204

SCHOMAKER, T.:

Ansätze zur Entwicklung einer Leistungsprüfung für funktionale Merkmale beim Milchrind. Schriftenreihe des Instituts für Tierzucht und Tierhaltung der Christian-Albrechts-Universität zu Kiel, Heft 128 (2001)

SÖLKNER, J.; MIESENBERGER, J.; WILLAM, A.; FUERST, CH.; BAUMUNG, R.: Total merit indices in dual purpose cattle. Arch. Tierz., Dummerstorf 43 (2000) 6, 597-608

SØRENSEN, M.K.; BERG, P.; JENSEN, J.; CHRISTENSEN, L.G.:

Stochastic simulation of breeding schemes for total merit in dairy cattle. Interbull Bull. 23 (1999), 183192

STATISTISCHES BUNDESAMT WIESBADEN:

Ökologischer Landbau 2001; Ergebnisse und Weiterentwicklung der statistischen Erfassung. Sonderdruck aus Wirtschaft und Statistik 06/2002

THALLER, G.; AUMANN, J.:

Genetic evaluation of male and female fertility. Interbull Bull. 12 (1996), 59-64

VAN DORP, T.; DEKKERS, J.; MASTIN, S.; NORDHUIZEN, J.:

Genetic parameters for clinical mastitis, somatic cell score, and milk production estimated by multiple trait restricted maximum likelihood. J. Dairy Sci. 81 (1998), 2264-2270

VEREINIGTE INFORMATIONSSYSTEME TIERHALTUNG w.W (VIT): Jahresbericht 2002

VOLLEMA, A.R.; VAN DER BEEK, S.; HARBERS, A.G.F.; DE JONG, G.: Genetic evaluation for longevity of Dutch dairy bulls. J. Dairy Sci. 83 (2000), 2629-2639

WILLAM, A.; EGGER-DANNER, C.; SÖLKNER, J.; GIERZINGER, E.:

Optimization of progeny testing schemes when functional traits play an important role in the total merit index. Livest. Prod. Sci. 77 (2002), 217-225

Received: 2003-12-23

Accepted: 2004-02-26

Authors` address

BIRTE HARDER, Dr. WOLFGANG JUNGE, Dr. JÖRN BENNEWITZ

Prof. Dr. Dr. h.c. mult. ERNST KALM

Institute of Animal Breeding and Husbandry

Olshausenstr. 40

D-24098 Kiel

Germany 